\title{
Relation between Problematic Internet Use and Mental Health Status of Technical Nursing Students in Tanta City
}

\author{
Hanan Abo El-Gamelen Ebrahim Essa ${ }^{(1)}$ and Zebeda Abd-Elgwad Elsherif ${ }^{(2)}$ \\ ${ }^{(\mathbf{1})}$ Assistant Professor of Community Health Nursing and ${ }^{(2)}$ Assistant Professor of Psychiatric \\ $\&$ Mental Health Nursing. Faculty of Nursing, Tanta University \\ h.aboelgamelen@gmail.com ․alsherif@gmail.com
}

\section{Abstract}

Background: Students are believed to be at a high risk with a marked increase in their internet usage worldwide. Problematic Internet use (PIU) is characterized by a lack of control over the concern, encouragement, or problems related to anxiety, stress and depression as a result of its use. Aim of the study: to identify the relation between problematic internet use and mental health status of technical nursing students in Tanta city. Design: A descriptive design was used in this study. This study was conducted at two secondary technical nursing schools and the technical health institute (nursing branch) in Tanta city. Subjects: A convenient sample of 273 students in the above mentioned schools was included in the study. Three tools were used by the researchers to obtain the necessary data, the structured questionnaire schedule, General health questionnaire (GHQ-28) and the Internet Addiction Test (IAT). Results: More than half of the studied students had frequent problems related to internet usage (56.4\%) and about one third of them $(31.9 \%)$ had a significant problems. Slightly less than two fifths of the studied subjects $(38.8 \%)$ had poor mental health. Significant differences were observed between the studied level of internet usage and their age, sex and social level $(\mathrm{P}=<0.001,0.009$ and 0.034) respectively. Conclusion: There were strong significant positive correlation between the level of internet usage and students' mental health status. Recommendations: Further studies needed to develop and implement rehabilitation programs, for students with psychological problems related to excessive internet usage.

Keywords: Problematic Internet Use, Technical Nursing Students, Mental Health and subjective happiness. 


\section{Introduction}

Internet becomes a critical part of modern life. As a medium of information and communication, it has an important place in social and academic life of nursing students in many societies. Today's students have unprecedented access to modern technology and use them in expected and unexpected ways. They spend many hours a day using it ${ }^{(1,2)}$. The internet is the most effective tool in all different areas of science, business, education, culture and politics. It brings a huge change and convince; people spend more and more time online, ranged from 19 to 68 hours per week. Worldwide, internet users were 1.2 billion in the year 2000 and increased to 3.17 billion in 2015 . According to the internet usage statistics in Egypt, internet users are $54.6 \%$ of the population in 2015 , compared to $35.6 \%$ in 2012. More than $80 \%$ of the Egyptian internet café clients are young people ${ }^{(3-7)}$.

However, while the internet has become a major information and communication medium for the students, the number of unhealthy or excessive internet users among them has also grown remarkably ${ }^{(5)}$. Problematic internet use refers to the excessive use of internet and significantly influences one's normal life including psychological, family and social life ${ }^{(6)}$. It is a maladaptive use of the internet that can lead to social and functional impairment $(7,8)$

Problematic Internet Use (PIU) is a heterogeneous construct. Two features appear fundamental to its conceptualization. The first refers to the aspects of internet use, as excessive or compulsive, along with preoccupation with and loss of control over use of the internet. The second refers to various adverse consequences of spending too much time on the internet, such as neglecting social activities, relationships, health and work or school duties, and altering sleep and eating habits in a detrimental way ${ }^{(4,9)}$.

Problematic internet use or overuse is not just a matter of using the internet to perform, or using an average amount of time on computers. Instead, compulsively use the internet, to such an extent that it is given priority over all other responsibilities which also affect time and attention to school work, domestic and responsibilities at home, and even interaction and relationships. Some examples and activities of internet overuse may include chatting online, playing online video games, or visiting sexually illicit or pornographic sites ${ }^{(10)}$. Five negative internet technology (IT) related issues were identified: techno-stress, information overload, multitasking, addictions, and technology misuse ${ }^{(11,12-14)}$. 
School age is a unique and formative time.

It is a time of self-disclosure and conflict to find a balance between autonomy and connectedness. It is a period in which an individual face major physical, psychological, body and brain changes. It may begin as early as age 6 and extend until age 24 . This age group represents one fifth of the global population. In Egypt, according to Egypt Demographic Profile 2018, the age group of 15-24 years represent $18.94 \%$ of the total population $(15,16)$. Whilst most of students have good mental health, multiple physical, emotional and social changes can make them vulnerable to mental health problems. They are vulnerable to misuse of internet technology if they have not been taught how to use it adequately or if they are without supervision when using it (17)

Technical nursing students are those students who enrolled in secondary nursing schools or institutes. Their ages ranged between 15-19 years. In general, those nurses are at a critical period of addiction vulnerability, based on their educational, social and also neurobiological factors. With regard to the internet they are more vulnerable and at risk as they have easy access to the internet and flexible timetables. Furthermore, they tend to be less self- regulative, and also have less ability to control their enthusiasm for internet activities ${ }^{(18-24)}$.

Promoting psychological well-being and protecting students from adverse experiences and risk factors which can impact their potential to thrive aren't only critical for his or her well-being during adolescence, but also for their physical and mental health in adulthood. Community health nurse and psychiatric nurse play an important role in promoting students' physical and psychological health, control health risk behavior to maintain normal development and managing actual and potential health problems facing them while using the internet ${ }^{(25)}$. They play a critical role especially at the primary level of prevention. The contact of these nurses with the students offers an opportunity to implement primary level of prevention in a most effective manner. This level of prevention might be instituted through such approaches as health promoter, educator, health screener, care provider and leader for health policies and programs ${ }^{(26)}$.

\section{Significance of the study}

The internet now is used as a tool to acquire new information, make contact with various social groups, and expand personal relationships. Recently, 
researches on the adverse effects of internet use have gained

a great importance ${ }^{(4)}$. Researchers have identified that the continuous use of internet results in a lot of psychological and mental disorders like anxiety, depression, stress and obsessive compulsive disorder. Furthermore, they found that Problematic Internet Use was associated with sleep problems including subjective insomnia and poor sleep quality $(27,28)$. However, there is currently insufficient data on internet use among technical school nurses. So, the aim of this study was to identify the relation between problematic internet use and mental health status of technical nursing students in Tanta city.

\section{Aim of the study:}

The aim of this study was to identify the relation between problematic internet use and mental health status of technical nursing students in Tanta city.

\section{Research question;}

Is there a relation between problematic internet use and mental health status of technical nursing students?

\section{Subjects and Method}

\section{Subjects:}

Study design: Descriptive research design was utilized to conduct this study.

Setting: This study was conducted at two secondary technical nursing schools (one school for male students and the other one for female students) in addition to the Technical Health Institute (nursing branch) in Tanta city that affiliated to Ministry of Health and Population.

\section{Study subjects:}

A convenient sample of 273 students of both sexes (92 Boys and 181 girls) enrolled in the previous mentioned settings during the academic year 2017/ 2018 that represent all the students from grade one to grade five who were willing to participate in the study who were live with their biological parents and who were free from any physical or psychological problems were included in the study.

\section{Tools of the study:}

Three tools were used to collect the necessary data as follow:

\section{Tool I: Structured questionnaire} schedule that consisted of three parts as follow:

\section{Part (1): Socio-demographic} characteristics of the study subjects which was developed by the researchers based on reviewing the recent related literatures, as age, sex, grade, birth order, residence, type of family, family income and daily expense.

\section{Part (2): The Family Affluence Scale}

(FAS) which developed by Curries 2008 (29) to assess the social level, the economic status of the students. It consists of four 
items as: number of cars does the family own, if the students have bedroom, the number of travel on vacation with their families during the past year and number of computers do their families own.

\section{Scoring system;}

FAS score ranged between 0-9. The FAS score was calculated by summing the responses to these four items, and the respondents were grouped into low social level (0-2), middle social level (3-5), and high social level (6-9).

Tool II: Mental health status of the studied students:

Part (1) General health questionnaire $\left(\right.$ GHQ-28) ${ }^{(30)}$ :

It was developed by Goldberg in 1978; it included 28 items to measure emotional distress in medical settings. The GHQ-28 has been divided into four subscales: somatic symptoms (items 1-7); anxiety/insomnia (items 8-14); social dysfunction (items 15-21), and severe depression (items 22-28). Each item is accompanied by four possible responses: not at all, no more than usual, rather more than usual, and much more than usual, scored from 0 to 3 for each response with a total possible score ranging from 0 to 84 .

\section{Scoring system;}

The students' mental health status was categorized as follow:
- Good mental health: $(<60 \%)=<50$ point of total score.

- Poor mental health: $(\geq 60 \%) \geq 50$ point of total score.

Part (2): The Subjective Happiness Scale (SHS) ${ }^{(31)}$.

The Subjective Happiness Scale (SHS) scale that was developed by Lyubomirsky and Lepper (1999) to assess the extent of overall subjective happiness among students was adopted by the researchers. It consisted of 4-items and assessed with a five-point Likert scale rated from 1 to 5 . The total score of the scale ranged from 4 20. This score was converted into a percent score, and classified into the following three categories:

- Not happy $<50 \%$ of the total happiness score.

- Happy 50-70 \% of the total happiness score.

- Very happy > 70\% of the total happiness score.

\section{Tool III: Internet Addiction Test (IAT):}

The internet addiction test is a reliable and valid measure of addictive use of internet, developed by Dr. Kimberly Young ${ }^{(32)}$. It consists of 20 items that measures mild, moderate and severe level of internet addiction answered in five likert scale ranging from 1 (rarely) to 5 (Always). The minimum score is 20 and the maximum is 100. The higher score indicates the greater 
problematic internet use. Young suggests that a score of 20-49 points is an average online user who has complete control over his/ her usage. A score of 50- 79 signifies frequent problems due to internet usage, and the score of $80-100$ means that the internet is causing significant problems.

\section{Method}

\section{1-Obtaining approvals}

Official permission to conduct the study was obtained from faculty of nursing to the responsible authorities to facilitate the researchers' work.

\section{2- Ethical considerations:}

- Approval of the ethical committee was obtained before conducting the study

- Informed consent was obtained from the students to participate in the study after explanation of the aim of the study.

- They were informed about their rights to refuse or withdraw at any time.

- The anonymity of participants was respected.

- The confidentiality of the information obtained was ensured.

- The privacy of the students was asserted.

- The study didn't cause harm to the studied subjects.

\section{3-Developing the tools}

- The study tools were developed by the researchers based on literature review. The developed tools were tested for content and face validity by a jury of 5 academic professors in community and psychiatric health nursing. Accordingly corrections and modifications were done.

- The reliability of the study tools were tested using Cronbach's Alpha test. It was 0.845 for all questionnaire variables, 0.857 for tool II and 0.919 for tool III which indicate a high reliability of studied tools.

- A pilot study was carried out on ten percent of study sample (27 students) to test the tool for its relevance and clarity. Modifications were done accordingly. Data collected from pilot part of the study were excluded from the final sample.

\section{4- The actual study}

- The collection of the data continued during a period of three months starting from beginning February2018 to April 2018.

- The data was collected by administering the questionnaire to each student individually to complete it by his / herself with the attendance of the researcher to offer guidance and clarification when needed.

- The average time spent for collecting 
data from each student was approximately $30-40$ minutes to complete the questionnaire.

\section{5- Statistical analysis}

The collected data were organized, tabulated and statistically analyzed using Statistical Package of Social Studies (SPSS) version 23. For numerical data, the range, mean and standard deviation were calculated. The association between variables was calculated by Pearson's correlation coefficient (r). For categorical variables, the number and percentage were calculated. Differences between categories of each variable were statistically analyzed using chi square test $\left(\mathrm{X}^{2}\right)$. The level of significance was adopted at $\mathrm{p}<0.05$.

\section{Results:}

Table (1) shows socio demographic characteristics of studied students. It was clear that more than two thirds of the studied subjects were females in the age group of $17-20$ years $(66.3 \%$ and $68.2 \%)$ respectively. More than two fifths of them were the oldest child who enrolled in the third grade and had a daily expense of 510 pound or more than 10 pounds per day $(41 \%, \quad 86.5 \%, \quad 41.8 \%$ and $40.7 \%)$ respectively. As regard the monthly income and residence, the table showed that nearly two thirds of the studied students had adequate income and from rural areas (63\%and 63.7\%) respectively.
More than half of them live with extended families (58.3\%) and the majority of them had excellent academic achievement (81\%).

Fig (1) presents the distribution of the studied subjects according to the mean of net connection. It was clear that the majority of the studied subjects use the mobile phone as a mean of net connection $(86 \%)$.

Fig (2) illustrates the distribution of the studied subjects according to their social level. More than half of the studied subjects $(55.7 \%)$ were of low social level and slightly less than two fifths of them (39.9\%) were from the middle social class Fig (3): shows the distribution of the studied subjects according to their level of subjective feeling of happiness. The figure showed that about one quarter of the studied subject had feeling of unhappy $(23 \%)$ while only $4.8 \%$ of the reported that they were very happy. Nearly about three quarters of the studied students $(72.2 \%)$ reported that they were happy.

Table 2: presents the distribution of the studied sample according to mental health status. Generally, slightly less than one fifth of the studied subjects $(38.8 \%)$ reported poor mental health. The total mean score of the students' mental health was $60.728 \pm 12.124$. As regard somatic manifestation, it was clear that more than 
one quarter of them had high level of somatic manifestation (25.6\%), while more than half of them had a higher level of insomnia/ anxiety (57.5\%) and high level of social dysfunction (62.3\%). As for depression status, more than one third of the studied subjects had severe level of depression $(35.5 \%)$.

Fig (4) illustrates the distribution of the studied subjects according to total mental health score. It was obvious that slightly less than two fifths of the studied subjects $(38.8 \%)$ had poor mental health.

Concerning the level of the problems that internet use cause, fig (5) showed that more than half of the studied students reported that they have frequent problems related to internet use $(56.4 \%)$ and about one third of them (31.9\%) reported significant problems related to internet usage.

Table (3): Presents the relation between levels of the problems that internet use cause and the general health status of the studied students. This table shows nearly about one third of the studied students had a high level of insomnia / anxiety and classified as having frequent or significant problems due to use of internet $(28.9 \%$ and $22.3 \%$ ) respectively. Furthermore, less than one fifth of them categorized had frequent or significant problem due to internet use were described as severe depression (17.2\% and $15.8 \%)$ respectively. However, around one fifth of the studied students with poor mental health status were classified as having frequent or significant problems due to internet use ( $19 \%$ and 17.2\%) respectively. Significant differences were observed between the level of the problems due to internet use and students' mental health status, insomnia/anxiety level and depression $(p=0.001,0.15$ and $0.003)$ respectively.

Table (4) presents the relation between socio-demographic characteristics of studied students and their level of problems caused by internet use. It was clear that more than one third of the studied subjects with frequent problems of internet use $(38.5 \%)$ were in the age group 7-20 years and about one fourth of the same age group had significant problems of internet use $(23.4 \%)$. More than one third of the studied subjects with frequent problems and about one fifth of those with significant problems of using internet were females $(37.7 \%$ and $18.3 \%)$. About one quarter of the studied subjects of low or middle social level had frequent problems (28.6\% and $24.2 \%)$ respectively.

Furthermore, the highest percentages of the studied students with significant problems related to internet use were found among the students of low and 
middle social level (17.9\% and $13.2 \%$ ) respectively compared to only $0.7 \%$ of the students of high social class. As regard the school grade, the table showed that the highest percentages of students with frequent and significant problems of internet use were found among the $3^{\text {rd }}$ grade students (26\% and 16.5\%) respectively.

The students of large families (five or more) particularly the extended families showed the highest frequencies of frequent and significant problems of internet use than those of small families $(31.1 \%$ and $16.1 \%)$ and (33\% and 19\%) respectively. The percentages of students with frequent and significant problems of internet use were found among the middle students of rural residence with adequate family income who use the mobile phone as a mean of net connection $(20.1 \%$ and $13.2 \%$, $35.9 \%$ and $19 \%, 33.7$ and $20.5 \%, 74.6 \%$ and $27.1 \%$ respectively. Significant differences were observed between the studied level of problems caused by internet use and their age, sex and social level $(\mathrm{P}=<0.001,0.009$ and 0.034$)$ respectively.

Table (5) shows the correlation between studied subjects' social level, mental health, happiness and level of problems caused by internet use. There were significant positive correlations between the level of the problems caused by internet use and students' mental health status and their social level ( $p<0.001$ and 0.022) respectively, while no significant correlations were found between level of happiness of the studied subjects and their level problems of internet use $(\mathrm{p}=0.317)$.

Table (6) shows the correlation between mental health status, happiness and problems caused by internet use and the socio-demographic characteristics of the studied subjects. The table showed that there were significant positive correlations between the level of the studied subjects' level of problems caused by internet use and their age, study grade and birth order $(p=0.001,0.001$ and 0.017$)$ respectively which means that the older students of higher academic grade have higher level of problematic internet use. Furthermore, strong significant correlation was observed between the sex of the studied subjects and their mental health status $(\mathrm{p}=0.008)$. On the other hand, significant negative correlation was found between sex of the students and their level of internet usage $(\mathrm{p}=0.024)$. Also, negative significant correlation was found between the student birth order and their mental health status $(p=0.020)$. 
Table 1: Socio demographic characteristics of studied students ( $\mathrm{No}=\mathbf{2 7 3})$.

\begin{tabular}{|c|c|c|}
\hline Socio demographic characteristics & No & $\%$ \\
\hline \multicolumn{3}{|l|}{ Age } \\
\hline Less than 17 years & 32 & 11.7 \\
\hline $17-20$ years & 186 & 68.2 \\
\hline More than 20 years & 55 & 20.1 \\
\hline Mean \pm SD & \multicolumn{2}{|c|}{$18.63 \pm 1.72$} \\
\hline Range & \multicolumn{2}{|c|}{$15-23$} \\
\hline \multicolumn{3}{|l|}{ Sex } \\
\hline Males & 92 & 33.7 \\
\hline Females & 181 & 66.3 \\
\hline \multicolumn{3}{|l|}{ Grade } \\
\hline $1^{\text {st }}$ grade & 34 & 12.5 \\
\hline $2^{\text {nd }}$ grade & 43 & 15.8 \\
\hline $3^{\text {rd }}$ grade & 127 & 46.5 \\
\hline $4^{\text {th }}$ grade & 41 & 15.0 \\
\hline $5^{\text {th }}$ grade & 28 & 10.2 \\
\hline \multicolumn{3}{|l|}{ Birth order } \\
\hline The oldest & 112 & 41.0 \\
\hline The middle & 99 & 36.3 \\
\hline The youngest & 62 & 22.7 \\
\hline \multicolumn{3}{|l|}{ Monthly income } \\
\hline Adequate and saving & 61 & 22.3 \\
\hline Adequate & 172 & 63.0 \\
\hline Inadequate & 40 & 14.7 \\
\hline \multicolumn{3}{|l|}{ Daily expense } \\
\hline Less than 5 pounds & 48 & 17.5 \\
\hline 5-10 pounds & 114 & 41.8 \\
\hline More than 10 pounds & 111 & 40.7 \\
\hline \multicolumn{3}{|l|}{ Residence } \\
\hline Urban & 99 & 36.3 \\
\hline Rural & 174 & 63.7 \\
\hline \multicolumn{3}{|l|}{ Family type } \\
\hline Nuclear family & 94 & 34.4 \\
\hline Extended family & 159 & 58.3 \\
\hline Single parent family & 20 & 7.3 \\
\hline \multicolumn{3}{|l|}{ Academic achievement } \\
\hline Weak & 13 & 4.8 \\
\hline Good & 39 & 14.2 \\
\hline Excellent & 221 & 81.0 \\
\hline
\end{tabular}




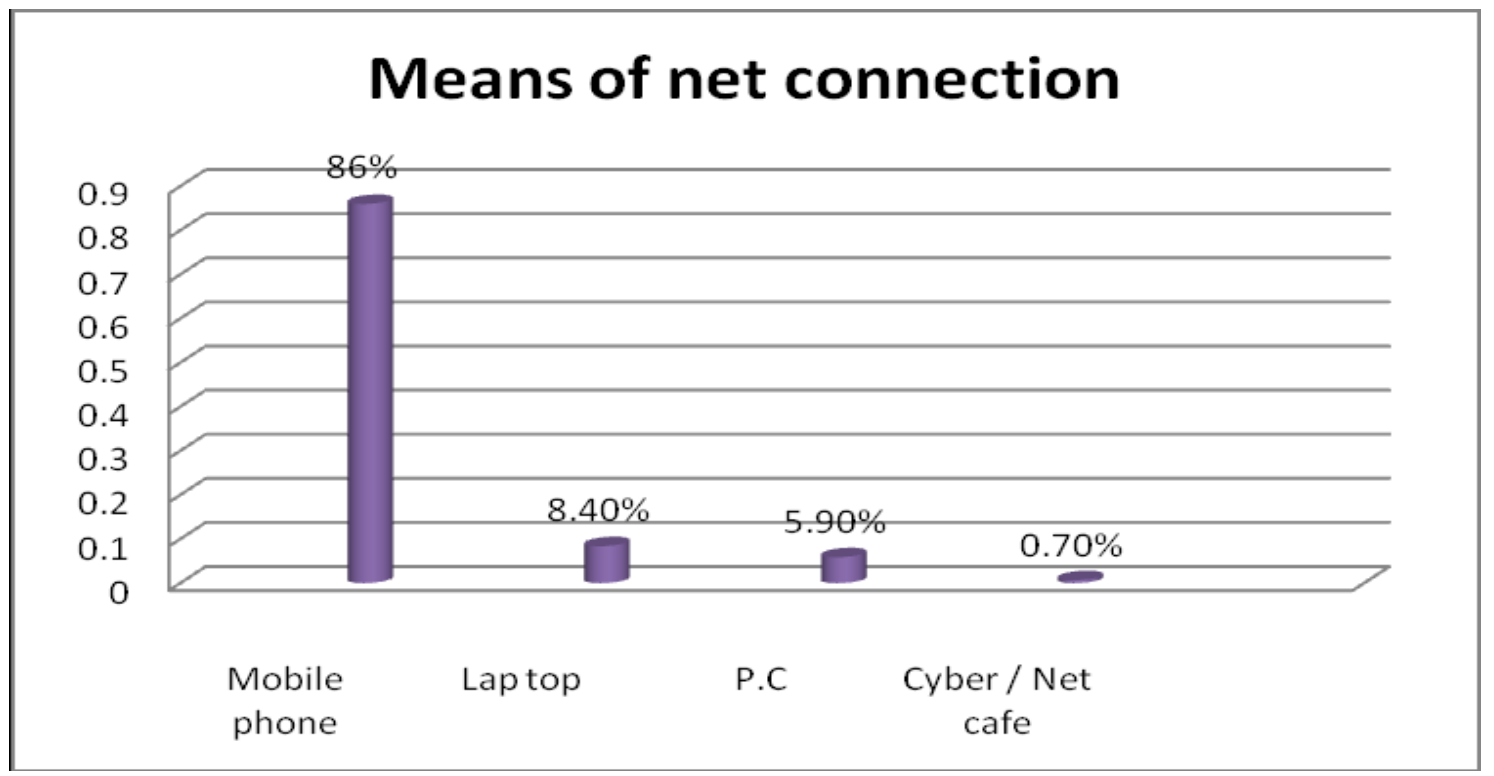

Fig (1): Distribution of the studied subjects according to the means of net connection

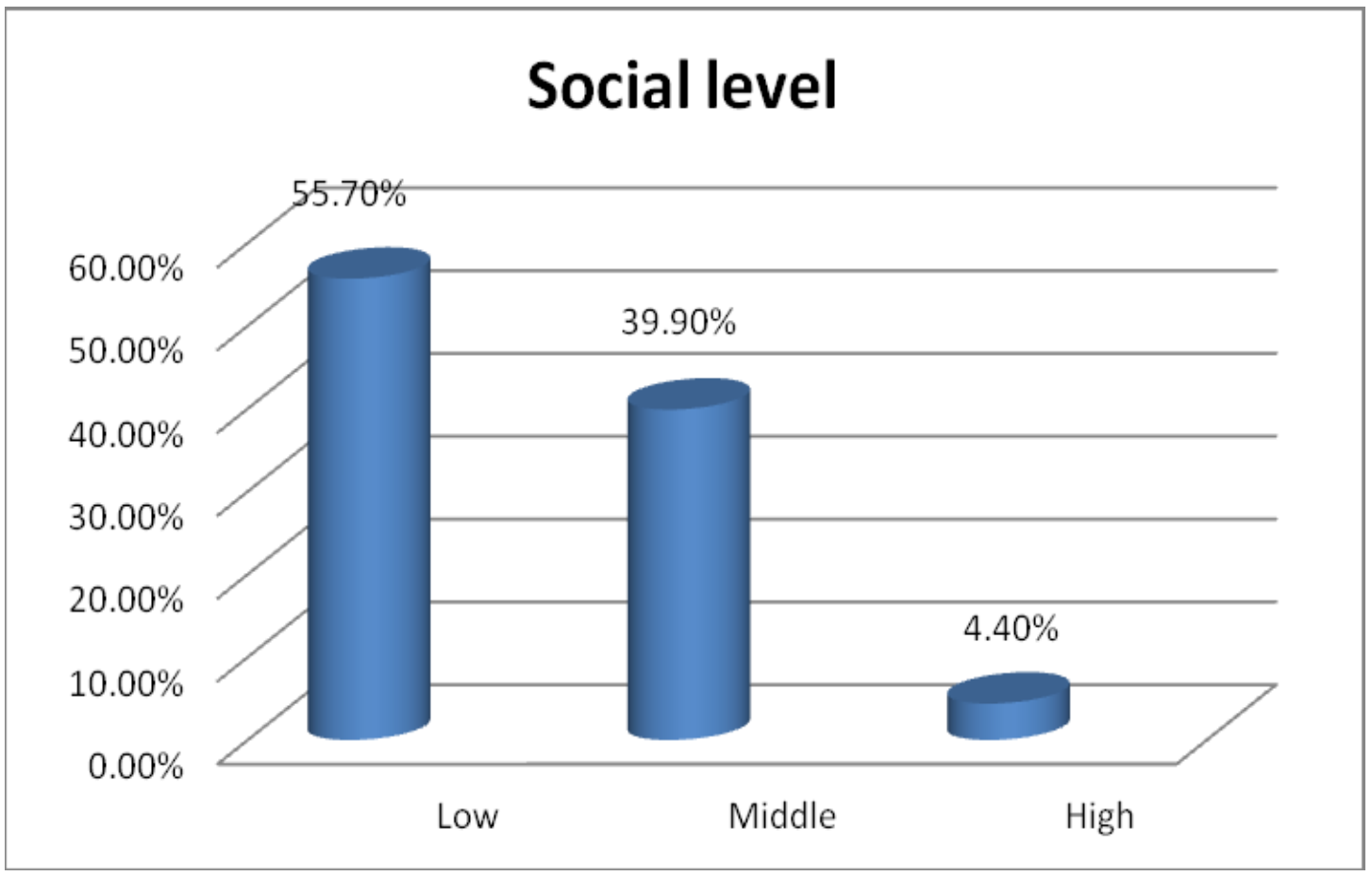

Fig (2): Distribution of the studied subjects according to their social level 


\section{Leve of subjective feeling of happiness}

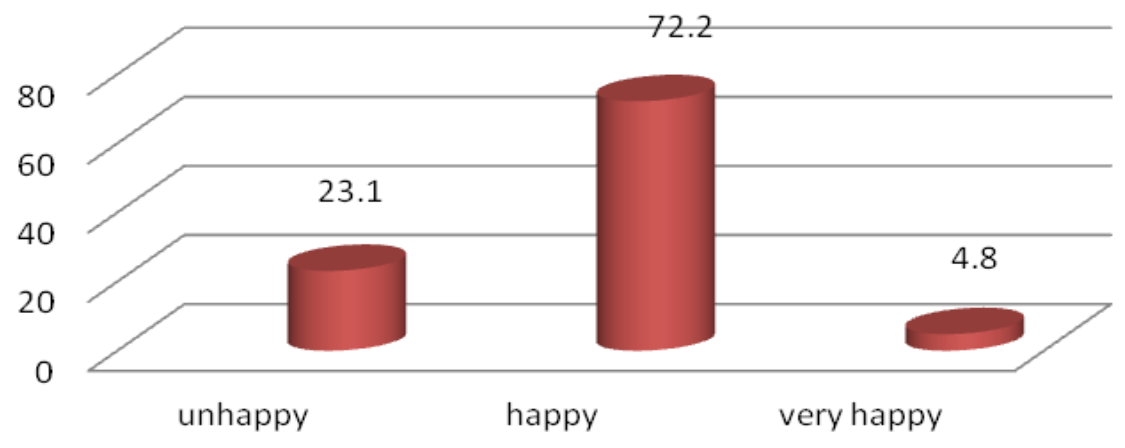

Fig (3): Distribution of the studied subjects according to level of subjective feeling of happiness

Table 2: Distribution of the studied sample according to mental health status

\begin{tabular}{|c|c|c|}
\hline Dimensions of mental health status & No & $\%$ \\
\hline $\begin{array}{l}\text { Somatic manifestation } \\
\text { Lower level of somatic manifestations } \\
\text { Higher level of somatic manifestations }\end{array}$ & $\begin{array}{c}203 \\
70\end{array}$ & $\begin{array}{l}74.4 \\
25.6\end{array}$ \\
\hline Mean \pm SD & \multicolumn{2}{|c|}{$14.12 \pm 3.81$} \\
\hline Range & \multicolumn{2}{|c|}{$7-28$} \\
\hline $\begin{array}{l}\text { Insomnia / anxiety } \\
\text { Lower level of insomnia / anxiety } \\
\text { Higher level of insomnia / anxiety }\end{array}$ & $\begin{array}{l}116 \\
157\end{array}$ & $\begin{array}{l}42.5 \\
57.5\end{array}$ \\
\hline Mean \pm SD & \multicolumn{2}{|c|}{$16.1319 \pm 4.76015$} \\
\hline Range & \multicolumn{2}{|c|}{$7-28$} \\
\hline $\begin{array}{l}\text { Social dysfunction } \\
\text { Low social dysfunction } \\
\text { High social dysfunction }\end{array}$ & $\begin{array}{l}103 \\
170\end{array}$ & $\begin{array}{l}37.7 \\
62.3\end{array}$ \\
\hline Mean \pm SD & \multicolumn{2}{|c|}{$16.5018 \pm 3.69033$} \\
\hline Range & \multicolumn{2}{|c|}{$8-27$} \\
\hline $\begin{array}{l}\text { Depression } \\
\text { Mild depression } \\
\text { Severe depression }\end{array}$ & $\begin{array}{c}176 \\
97\end{array}$ & $\begin{array}{l}64.5 \\
35.5\end{array}$ \\
\hline Mean \pm SD & \multicolumn{2}{|c|}{$13.9560 \pm 5.17185$} \\
\hline Range & \multicolumn{2}{|c|}{$7-28$} \\
\hline $\begin{array}{l}\text { Mental health status } \\
\text { Good mental health } \\
\text { Poor mental health }\end{array}$ & $\begin{array}{l}167 \\
106\end{array}$ & $\begin{array}{l}61.2 \\
38.8\end{array}$ \\
\hline Mean \pm SD & \multicolumn{2}{|c|}{$60.728 \pm 12.124$} \\
\hline Range & \multicolumn{2}{|c|}{$36-93$} \\
\hline
\end{tabular}

Vol. 19 No. 1 November, 2020 


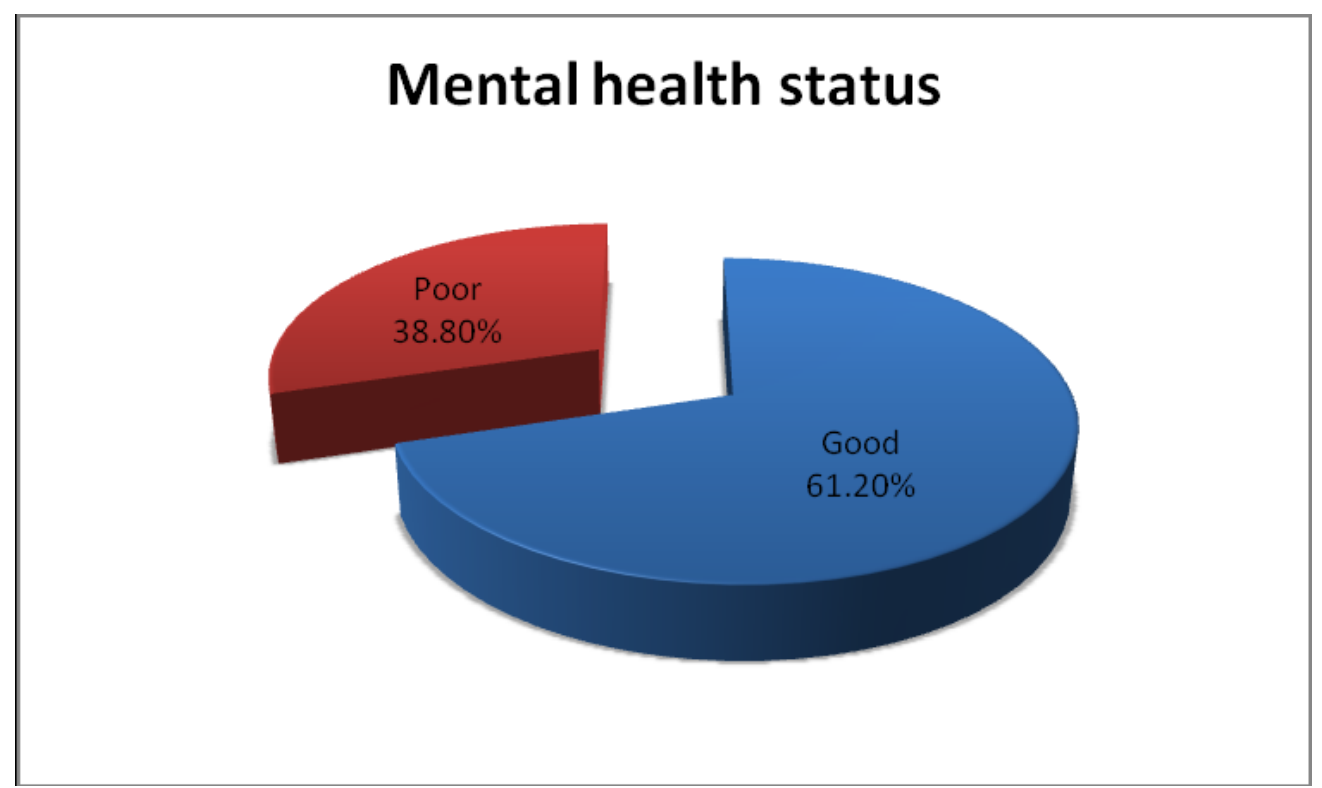

Fig (4): Distribution of the studied subjects according to total mental health score

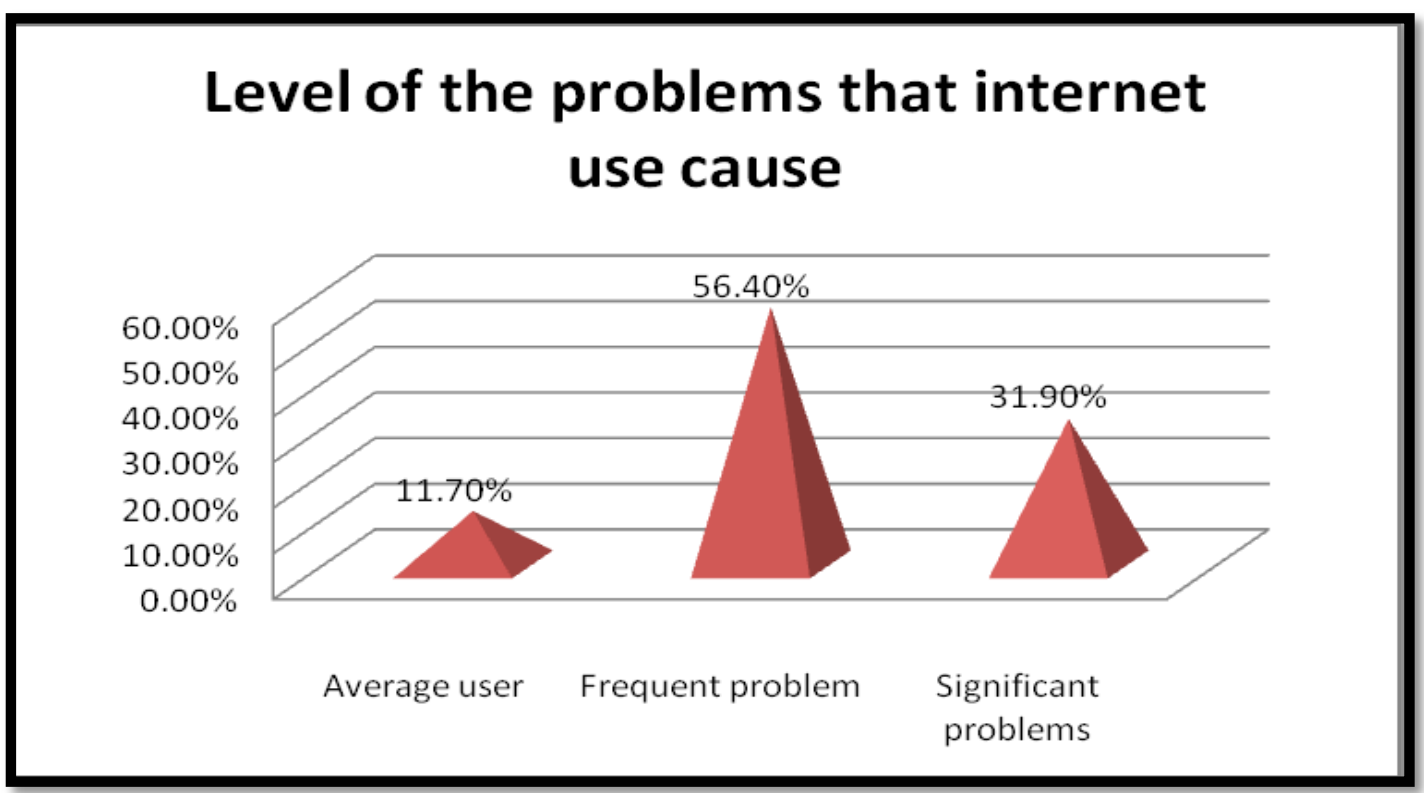

Fig (5): Distribution of the studied subjects according to level of the problems that internet use cause 
Table (3): Relation between the level of problem that internet use cause and studied students' general health status.

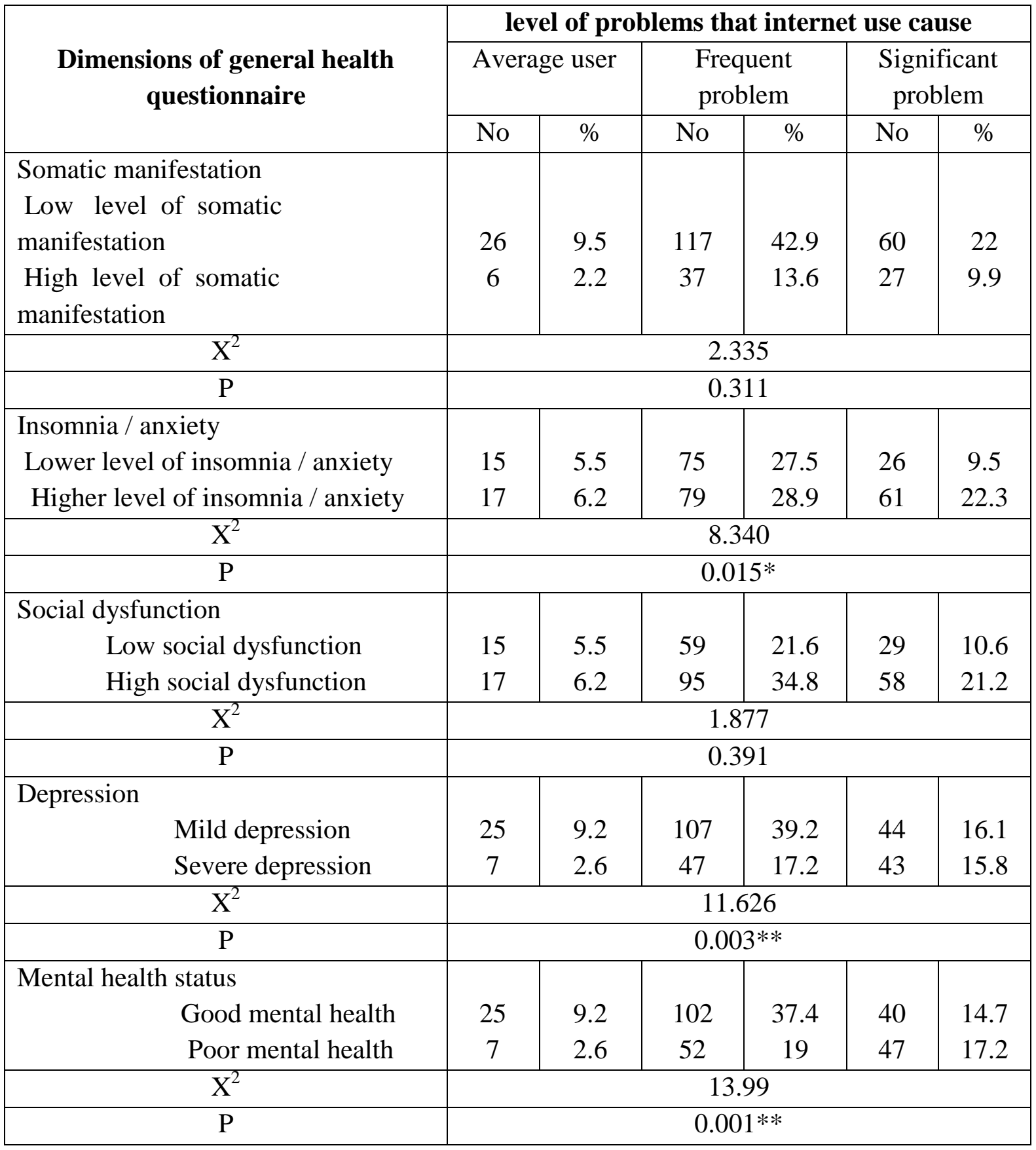


Table 4: Relation between socio-demographic characteristics of the studied students and their level of problems caused by internet use $(\mathrm{No}=274)$.

\begin{tabular}{|c|c|c|c|c|c|c|c|c|}
\hline \multirow{3}{*}{$\begin{array}{l}\text { Socio-demographic } \\
\text { characteristics }\end{array}$} & \multicolumn{8}{|c|}{ level of problems caused by internet use } \\
\hline & \multicolumn{2}{|c|}{$\begin{array}{c}\text { Average } \\
\text { use }\end{array}$} & \multicolumn{2}{|c|}{$\begin{array}{l}\text { Frequent } \\
\text { problems }\end{array}$} & \multicolumn{2}{|c|}{$\begin{array}{c}\text { Significant } \\
\text { problems }\end{array}$} & \multirow[t]{2}{*}{$\mathbf{X}^{2}$} & \multirow[t]{2}{*}{$\mathbf{P}$} \\
\hline & No & $\%$ & No & $\%$ & No & $\%$ & & \\
\hline $\begin{array}{l}\text { Age } \\
\text { Less than } 17 \text { years } \\
17-20 \text { years } \\
\text { More than } 20 \text { years }\end{array}$ & $\begin{array}{c}11 \\
17 \\
4\end{array}$ & $\begin{array}{c}4 \\
6.2 \\
1.5\end{array}$ & $\begin{array}{c}20 \\
106 \\
29\end{array}$ & $\begin{array}{c}7.3 \\
38.5 \\
10.6 \\
\end{array}$ & $\begin{array}{c}1 \\
64 \\
22\end{array}$ & $\begin{array}{c}0.4 \\
23.4 \\
8.1 \\
\end{array}$ & 26.153 & $<0.001 * *$ \\
\hline $\begin{array}{c}\text { Males } \\
\text { Females }\end{array}$ & $\begin{array}{c}4 \\
28\end{array}$ & $\begin{array}{c}1.5 \\
10.3\end{array}$ & $\begin{array}{c}51 \\
103\end{array}$ & $\begin{array}{l}18.7 \\
37.7\end{array}$ & $\begin{array}{l}37 \\
50\end{array}$ & $\begin{array}{l}13.6 \\
18.3\end{array}$ & 9.496 & $0.009 * *$ \\
\hline $\begin{array}{l}\text { Grade } \\
\qquad \begin{array}{l}1^{\text {st }} \text { grade } \\
2^{\text {nd }} \text { grade } \\
3^{\text {rd }} \text { grade } \\
4^{\text {th }} \text { grade } \\
5^{\text {th }} \text { grade }\end{array}\end{array}$ & $\begin{array}{c}9 \\
7 \\
11 \\
3 \\
2\end{array}$ & $\begin{array}{c}3.3 \\
2.6 \\
4 \\
1.1 \\
0.7\end{array}$ & $\begin{array}{l}21 \\
24 \\
71 \\
23 \\
15\end{array}$ & $\begin{array}{l}7.7 \\
8.8 \\
26 \\
8.4 \\
5.5\end{array}$ & $\begin{array}{c}4 \\
12 \\
45 \\
15 \\
11\end{array}$ & $\begin{array}{c}1.5 \\
4.4 \\
16.5 \\
5.5 \\
4\end{array}$ & 15.287 & 0.054 \\
\hline $\begin{array}{c}\text { No of family members } \\
\text { Three or less } \\
\text { Four members } \\
\text { Five or more }\end{array}$ & $\begin{array}{c}2 \\
5 \\
25\end{array}$ & $\begin{array}{l}0.7 \\
1.8 \\
9.2\end{array}$ & $\begin{array}{l}22 \\
47 \\
85\end{array}$ & $\begin{array}{c}8.1 \\
17.2 \\
31.1\end{array}$ & $\begin{array}{l}19 \\
24 \\
44\end{array}$ & $\begin{array}{c}7 \\
8.8 \\
16.1\end{array}$ & 9.446 & 0.051 \\
\hline $\begin{array}{l}\text { Birth order } \\
\text { The oldest } \\
\text { The middle } \\
\text { The youngest }\end{array}$ & $\begin{array}{c}18 \\
8 \\
6\end{array}$ & $\begin{array}{l}6.6 \\
2.9 \\
2.2\end{array}$ & $\begin{array}{l}63 \\
55 \\
36\end{array}$ & $\begin{array}{l}23.1 \\
20.1 \\
13.2\end{array}$ & $\begin{array}{l}31 \\
36 \\
20\end{array}$ & $\begin{array}{c}11.4 \\
13.2 \\
7.3 \\
\end{array}$ & 4.440 & .350 \\
\hline $\begin{array}{l}\text { Family income } \\
\text { Adequate and save } \\
\text { Adequate } \\
\text { Inadequate }\end{array}$ & $\begin{array}{c}6 \\
24 \\
2\end{array}$ & $\begin{array}{l}2.2 \\
8.8 \\
0.7\end{array}$ & $\begin{array}{l}38 \\
92 \\
24\end{array}$ & $\begin{array}{c}13.9 \\
33.7 \\
8.8\end{array}$ & $\begin{array}{l}17 \\
56 \\
14\end{array}$ & $\begin{array}{c}6.2 \\
20.5 \\
5.1\end{array}$ & 3.639 & .457 \\
\hline $\begin{array}{l}\text { Daily expense } \\
\text { Less than } 5 \text { pounds } \\
5-10 \text { pounds } \\
\text { More than } 10 \text { pounds }\end{array}$ & $\begin{array}{c}4 \\
20 \\
8\end{array}$ & $\begin{array}{l}1.5 \\
7.3 \\
2.9\end{array}$ & $\begin{array}{l}26 \\
65 \\
63\end{array}$ & $\begin{array}{c}9.5 \\
23.8 \\
23.1\end{array}$ & $\begin{array}{l}18 \\
29 \\
40\end{array}$ & $\begin{array}{c}6.6 \\
10.6 \\
14.7\end{array}$ & 8.311 & .081 \\
\hline $\begin{array}{ll}\text { Residence } & \\
& \text { Rural } \\
\text { Urban }\end{array}$ & $\begin{array}{c}24 \\
8\end{array}$ & $\begin{array}{l}8.8 \\
2.9\end{array}$ & $\begin{array}{l}98 \\
56\end{array}$ & $\begin{array}{l}35.9 \\
20.5\end{array}$ & $\begin{array}{l}52 \\
35\end{array}$ & $\begin{array}{c}19 \\
12.8\end{array}$ & 2.349 & .309 \\
\hline $\begin{array}{l}\text { Family type } \\
\text { Nuclear family } \\
\text { Extended family } \\
\text { Single parent family }\end{array}$ & $\begin{array}{c}12 \\
17 \\
3\end{array}$ & $\begin{array}{l}4.4 \\
6.2 \\
1.1\end{array}$ & $\begin{array}{l}53 \\
90 \\
11 \\
\end{array}$ & $\begin{array}{c}19.4 \\
33 \\
4\end{array}$ & $\begin{array}{c}29 \\
52 \\
6\end{array}$ & $\begin{array}{c}10.6 \\
19 \\
2.2\end{array}$ & .510 & 0.973 \\
\hline $\begin{array}{l}\text { Social level } \\
\text { Low } \\
\text { Middle } \\
\text { High }\end{array}$ & $\begin{array}{c}25 \\
7 \\
0\end{array}$ & $\begin{array}{l}9.2 \\
2.6 \\
0.0\end{array}$ & $\begin{array}{l}78 \\
66 \\
10\end{array}$ & $\begin{array}{c}28.6 \\
24.2 \\
3.7\end{array}$ & $\begin{array}{c}49 \\
36 \\
2\end{array}$ & $\begin{array}{c}17.9 \\
13.2 \\
0.7\end{array}$ & 10.409 & $.034 *$ \\
\hline $\begin{array}{c}\text { Means of net connection } \\
\text { Mobile phone } \\
\text { Lap top } \\
\text { P.C } \\
\text { Cyber / Net cafe }\end{array}$ & $\begin{array}{c}28 \\
2 \\
2 \\
00\end{array}$ & $\begin{array}{l}10.3 \\
0.7 \\
0.7 \\
0.0\end{array}$ & $\begin{array}{c}130 \\
13 \\
10 \\
1\end{array}$ & $\begin{array}{l}47.6 \\
4.8 \\
3.7 \\
0.4\end{array}$ & $\begin{array}{l}74 \\
8 \\
4 \\
1\end{array}$ & $\begin{array}{c}27.1 \\
2.9 \\
1.5 \\
0.4\end{array}$ & 1.076 & 0.983 \\
\hline $\begin{array}{c}\text { Academic achievement } \\
\text { Weak } \\
\text { Good } \\
\text { Excellent }\end{array}$ & $\begin{array}{c}0 \\
4 \\
28\end{array}$ & $\begin{array}{c}0.0 \\
1.5 \\
10.3\end{array}$ & $\begin{array}{c}7 \\
17 \\
130\end{array}$ & $\begin{array}{c}2.6 \\
6.2 \\
47.6\end{array}$ & $\begin{array}{c}6 \\
18 \\
63\end{array}$ & $\begin{array}{c}2.2 \\
6.6 \\
23.1\end{array}$ & 7.258 & 0.123 \\
\hline
\end{tabular}

Significant at $<0.05$ 
Table 5: Correlation between studied students'social level, mental health, happiness and level of the problems caused by internet use.

\begin{tabular}{|c|c|c|}
\hline \multirow{2}{*}{ Mental health } & Level of problems caused by internet use \\
\cline { 2 - 3 } & 0.331 & $\mathbf{p}$ \\
\hline Happiness level & 0.113 & $<0.001^{* *}$ \\
\hline Social level & 0.256 & 0.317 \\
& & $0.022^{*}$ \\
\hline
\end{tabular}

**. Correlation is significant at the 0.01 level.

*. Correlation is significant at the 0.05 level

Table 6: Correlation between mental health status, happiness level and level of problems caused by internet use and the socio-demographic characteristics of the studied subjects

\begin{tabular}{|c|c|c|c|c|c|c|}
\hline \multirow{2}{*}{$\begin{array}{c}\text { Sociodemographic } \\
\text { data }\end{array}$} & \multicolumn{2}{|c|}{$\begin{array}{c}\text { Mental health } \\
\text { status }\end{array}$} & \multicolumn{2}{c|}{$\begin{array}{c}\text { Happiness } \\
\text { level }\end{array}$} & \multicolumn{2}{c|}{$\begin{array}{c}\text { Level of problems caused by } \\
\text { internet use }\end{array}$} \\
\cline { 2 - 7 } Age & $\mathbf{r}$ & $\mathbf{p}$ & $\mathbf{r}$ & $\mathbf{p}$ & $\mathbf{r}$ & $\mathbf{p}$ \\
\hline Sex & -.043 & 0.482 & .038 & 0.531 &. .225 & $0.001^{* *}$ \\
\hline Grade & -.160 & $0.008^{* *}$ & .103 & .091 & -.137 & $.024^{*}$ \\
\hline Birth order & -.141 & $.020^{*}$ & -.064 & .289 & 0.145 & $.001^{* *}$ \\
\hline Daily expense & 0.005 & 0.935 & .092 & .128 & .052 & $0.017^{*}$ \\
\hline Residence & -0.050 & 0.407 & .011 & 0.859 & 0.078 & 0.200 \\
\hline
\end{tabular}

**. Correlation is significant at the 0.01 level.

*. Correlation is significant at the 0.05 level 


\section{Discussion}

Internet now has become indispensable for both individual and societal life. As the result of technology revolution worldwide, the accessibility, duration, and dependence level on internet increased day by day. Nursing students use the internet for learning and providing information, but they are also at risk of problematic internet use. ${ }^{(33,34)}$. Scientific studies have found that excessive use of internet is related to a variety of negative psychosocial consequences ${ }^{(33)}$. Therefore, the present study aimed to identify the relation between problematic internet use and mental health status of nursing students in Tanta city.

As regard to the mean of net connection, the majority of our subjects use mobile phone as a mean of net connection. This can be attributed to the availability of mobile phones and the accessibility of mobile net connection throughout the world. This result was supported by the results of Shaheen et al (2016) ${ }^{(35)}$, Parel and Thomas (2017) ${ }^{(36)}$, and Gopala VV et al. (2014) $)^{(37)}$, who mentioned that the majority of their subjects were predominantly use mobile phone for internet connection as the primary object for the internet usage. In contrast, this result disagree with the result of Aylaz et al. (2015) $)^{(\mathbf{3 8})}$ who found that $74.4 \%$ had a computer at home. They connected to the internet mostly at home and in internet cafes.

As for the degree of internet use, the current study revealed that only $11.7 \%$ of the studied subjects were average user of internet while the majority of them were identified to have frequent and significant problem related to internet usage. This result was in agreement with Khalil etal (2016) ${ }^{(39)}$ who reported that $38.4 \%$ and $2.1 \%$ of their participants were categorized as moderate to severe internet addiction and with Parel and Thomas $\mathbf{( 2 0 1 7 )}^{(\mathbf{3 6})}$ who reported that about $17.52 \%$ of students reported with no addiction while problematic use of internet was prominent feature among the rest of their subjects ranging from mild, moderate and sever net addiction.

In the same line the result of Mohamed et al (2019) ${ }^{(\mathbf{4 0 )}}$ who found that The majority $(82.3 \%)$ of participants reported frequently staying online longer than intended. Meanwhile, the current result contradict with the result of Cao et al (2011) ${ }^{(41)}$. In their study, they identified only $8.1 \%$ of the students with problematic Internet users. Moreover, there have been several studies about the prevalence rate of Internet addiction in the middle and Far East. Among those studies an Iranian study 
done by Mazhari (2012) ${ }^{(\mathbf{4 2})}$ examining the

prevalence of IA among medical students as she found that $21 \%$ of the students were identified as problematic Internet users, and Kheirkhah et al. (2010) ${ }^{(43)}$ investigated the prevalence of Internet addiction in the Mazandaran province as they found that $22.8 \%$ of the Internet users were Internet addicts. From the researchers' point of views, this variation could be related to cultural diversity among participants or different tools that were used to measure the internet usage level among the participants.

It was reported that as problematic internet use increased, the general individuals' health declined and insomnia associated with increased prevalence of depressive symptoms emerged ${ }^{(6)}$. In this regard, the current study revealed that more than one quarter of the studied students had low level of psychosomatic manifestation and more than one third of them had low level of mental health status. More than one third of them categorized as severe depression while more than half of them were categorized as of higher level of insomnia / anxiety and high level of social dysfunction.

This is in agreement with the study of Malak et al, $2017^{(44)}$ who revealed that Jordanian school students had high prevalence of anxiety and depression indicating a relationship between anxiety, depression and IA. They explained this as the school students aged 12-18 undergo many developmental changes leading them to experience social and psychological problems, therefore Internet is considered as rich environment to fulfill their needs and forget their problems. As for the relation of problematic use of internet and the general health of the studied subjects, the current result indicated that there was strong significant positive correlation between level of internet use and mental health condition of the studied subjects. This result is in agreement with the results of Andersona et al ( 2016$)^{(45)}$.

Additionally, an Australian study which concluded that the links between PIU and anxiety, social anxiety, depression and general psychological distress have been examined mainly as predictors, and less as potential consequences of PIU, across predominantly Asian populations (Korean, Singaporean) ${ }^{(46)}$. Finally, there have been contradictory findings considering the association between psychotic symptoms and PIU, with one study that support our results and suggesting that an increase in psychotic symptoms over two-months related to significantly higher PIU (Mittal et al, 2013) ${ }^{(47)}$, and a second study which 
disagree with ours, resulting in no significant associations (Dong et al, 2011) ${ }^{(48)}$. A statistically significant relationship was found between level of insomnia / anxiety and problematic internet use. Nearly about one quarter of the studied student who were categorized as frequent or significant problems related to internet use were described to had high level of insomnia / anxiety. This result was in the same line of the result of Aylaz et al. (2015) ${ }^{(38)}$ who reported that there was a statistically significant relationship between sleeping problems and problematic internet use among their participants. Furthermore, the current results revealed that the prevalence of severe depression among the studied students was statistically related to the problematic internet use.

This result is support the finding of other studies (Malak et al.2017, Çam, et al 2015, Goel ae al,2013 and Tang at al,2014) ${ }^{(44,49-51)}$ indicating a relationship between anxiety, depression and problematic use of internet. This can be explained as adolescents undergo many developmental changes leading them to experience social and psychological problems, therefore internet is considered as rich environment to fulfill their needs and forget their problems.

Risk factors for problematic internet use have been reported to include social factors as age, gender, birth order, level education, unsatisfactory financial situation and social leveling (38). Many studies have investigated gender differences in internet addiction (Kaynak et al, $2018^{(52)}$, Şahin, $2011^{(53)}$, Tonioni et al, $2012^{(54)}$; and Wu et al, $2015^{(55)}$. These studies found that the "Internet addiction" total scores, and the problems in social relationships subscale scores were higher in male nurses than in their female colleagues.

This result disagree with the result of the current study which revealed that there was a significant negative correlation between internet problematic use and the sex of the studied students and the females were more apt to have either frequent or significant problem related to internet use. This can be attributed to the Arab culture particularly in rural areas in Egypt that restrict the hiking of females so, they tend to spend their time using internet seeking for companionship, building social relationship and sharing feelings and ideas. In the same line, other studies (Aylaz at.al, $2015^{(38),}$, Malak et al, $2017^{(44)}$ and Rücker et al, $2015^{(56)}$ reported that the average girls seem to be affected more by the negative results of the internet more than boys.

One of the findings of this study was that the high prevalence was among students 
aged 17-20 years. Significant positive correlation was observed between the age of the studied subjects and the problematic internet use. This indicates that this group is more prone to excessive Internet usage than younger adolescents. This may be explained as the older adolescents experience serious problems associated with studying. This supported by Wu et al. (2016) (55) who reported that late adolescents (aged 15-18) had a higher prevalence of IA compared to early adolescents (aged 11-14). On the other hand, this result disagree with the study of Ko et al, (2012) ${ }^{(57)}$ who indicated that age was associated with IA in junior high school male students.

The current study revealed that significant positive correlation was observed between the students' academic grade and problematic internet use. It showed that the prevalence of frequent or significant internet use was higher in the third grade and the higher grades. This may attributed to the stresses that those students face during preparation of assignments and other assigned duties needed for clinical assessment and studying for examination. The findings of this study are contradict with a previous researches (Sasmaz et al, $2013^{(58)}$ and Malak et al, $2017^{(44)}$ that showed the prevalence of IA was higher in the first secondary class than the second secondary.

The current results showed that significant difference was observed between students' social level and problematic internet use indicated that students of low social level had high rates of frequent or significant problematic use of internet. This may be because of the students of high social level can spend much of their times in traveling or at clubs or gem while those of low social level haven't this chance of recreation so, they spend their times on internet either for gaming or for communication with their peers. This result stresses the need of these families for interventions and strategies regarding the risks of Internet and PIU. Excessive internet use among adolescents was correlated with poorer financial standards, as was found in previous studies (Lam $\boldsymbol{e t}$ al, $2009^{(59)}$; Tsai et al, $2009^{(60)}$.

Additionally, the finding of the current study is similar to past research findings of Wu et al. (2016) (55) study who documenting that adolescents with low family income had high rates of IA. Meanwhile, this result inconsistent with the findings of (Malak at al,2017 ${ }^{(44)}$ and Alhantoushi et al, 2014 (61) who mentioned that students with high family income had high percentage of IA. They attributed their result to the assumption 
that high-income families obtain both computer and internet connection services at home.

Subjective happiness is a state of mind or feeling characterized by pleasure or satisfaction. Since subjective happiness is correlated to satisfying relationships, positive emotions, self-perceptions of well-being, satisfaction with life, the negative effect of internet addiction on subjective happiness seems very reasonable. The result of current study revealed that nearly about three quarters of the studied subjects were feeling happy while less than one quarter of them were unhappy. However, the result of this study revealed that no significant correlations were found between the level of problematic internet use and level of happiness among the studied students.

This finding is inconsistent with previous research (Akın 2011) ${ }^{(62)}$, which found that a more problematic Internet use is associated with a lower subjective happiness. A greater dependent use of the Internet was negatively linked to psychological well-being and subjective happiness.

\section{Conclusion}

In the light of the results of the current study it was concluded that, the majority of the studied students have a frequent and significant problem in relation to internet usage which has a devastating effect on the students' mental health. Significant positive correlation was found between mental health status and the level of problems caused by internet use. The students with significant problems related to internet use reported poor mental health status. Also, it was concluded that the most affected students were females of the age group of 17-20 years old. Significant positive correlations were observed between the level of internet usage and the students' age, grade and birth order where the older students of higher academic grade were classified as having frequent or significant problematic internet use. In addition, significant positive correlations were found between studied students' mental health status and their sex and birth older.

\section{Recommendations}

- Health-promotion strategies should be implemented and evaluated in respond to problematic internet use.

- Emphasizing the role of multimedia in advocating sound internet usage.

- Further studies needed to develop and implement of rehabilitation programs, for students with psychological problems related to excessive internet usage.

- Professional monitoring in collaboration with community-based 
mental health centers, youth counseling centers, and other similar facilities is needed to provide affected students with solution-oriented professional support.

- Future studies need to develop and implement rehabilitation programs, such as camp or therapeutic schools, for students with problems related to excessive internet usage, and to verify the effects of such programs.

\section{References}

1. Simuforosa M. The impact of modern technology on the educational attainment of adolescents. International Journal of Education and Research, 2 013; 1 (9): 1-8.

2. Richards R, McGee R, Williams S and Welch D. Adolescent Screen Time and Attachment to Parents and Peers. Archives of Pediatrics and Adolescent Medicine, 2010;164(3):258-262.

3. Shaw J, Mitchell C, Anthony J, Welch A and Williamson M. Social media used as a health intervention in adolescent health: A systematic review of the literature. Digital Health, 2015 :1-10.

4. Statista. Number of internet users worldwide from 2005 to 2015 in millions, 2015. Available at: http://www.statista.com/statistics/2730 18/numberof- internet
5. Lewis S. Where young adults intend to get news in five years? Newspaper Research Journal, 2008; 29(4):36-52.

6. Internet world status. Egypt internet usage and telecommunications report, 2012. Available at: http://www.internet worldstats.com/af/eg.htm.

7. United Nations development programme (UNDP) and institute of national planning (INP). Egypt human development report 2010: Youth in Egypt: Building our Future, 2010. Available at: http://www.undp.org.eg/ Portals/english.pdf.

8. Hilarie C, Cosette D, Ann H. Internet Addiction: A Brief Summary of Research and Practice, Current Psychiatry Reviews, 2012; 8:292-298.

9. Navas A, Olalla M, Aguilar V, Hurtado J, García G. and Andreu J. Mental Health Promotion: Prevention of Problematic Internet Use among Adolescents. J of Psychiatry 2015, $18: 1$

10. Morah D and Uzochukwu C. New media and climate change communication in Nigeria. Journal of Communication and Media Research, 2012; 4 (2): 119 -132.

11. Solo-Anaeto $M$ and Jacobs $B$. Exploring Social Media as Channels for Sustaining African Culture, 
International Journal of Humanities and Social Science, 2015; 5 4(1): 37 42.

12. Natalie Gerhart. Technology Addiction: How social network sites impact our lives. the International Journal of an Emerging Transdiscipline, 2017, Volume 20, 179-194

13. Afusat Olanike Busari. Academic Stress and Internet Addiction among Adolescents: Solution Focused Social Interest Programme as Treatment Option. Busari, J Ment Disord Treat 2016, Volume 2 ,Issue 2, 1-10

14. Stéphanie Laconi, Rachel Florence Rodgers , Henri Chabrol, The measurement of Internet addiction: A critical review of existing scales and their psychometric properties. Computers in Human Behavior 41 (2014) 190-202)

15. Crosnoe R, Johnson M. Research on adolescence in the twenty-first century. Annual Review of Sociology, 2011;37:439-460.

16. IndexMundi. Egypt Demographics Profile 2018 - Index Mundi, 2018. Available at: https://www.indexmundi .com/egypt/demographics _profile.html

17. WHO, Adolescent mental health, 18 September 2018, available at: https://www.who.int/news-room/factsheets/detail/adolescent-mental-health

18. Liu D and Baumeister R. Social networking online and personality of self-worth: A meta-analysis. Journal of Research in Personality, 2016; 64: 7989.

19. Cramer S and Inkster B. Status Of Mind: Social media and young people's mental health and wellbeing. (Report.) London, England: Royal Society for Public Health (UK) and Young Health Movement (UK),2017.

20. Jelenchick L, Eickhoff J, Zhang C, Kraninger K, Christakis D and Moreno M. Screening for adolescent problematic Internet use: validation of the Problematic and Risky Internet Use Screening Scale (PRIUSS). Acad Pediatr, 2015;15(6):658-665.

21. Syed Shah Alam, Nik Mohd. Hazrul Nik Hashim, Maisarah Ahmad. Negative and positive impact of internet addiction on young adults: Empericial study in Malaysia. Intangible Capital IC, 2014 - 10(3): 619-638)

22. Lu Xi, Yeo Kee Jiar. Depression and Internet use in a Sample of Malaysian Undergraduate Students. Journal of Education and Vocational Research ,Nov 2013, Vol. 4, No. 11, pp. 317325) 
23. Erkan Tekinarslan, Melih Derya Gürer.

Problematic Internet use among Turkish university students: A multidimensional investigation based on demographics and Internet activities. Volume: 8 Issue: 1 Year: 2011, International Journal of Human Sciences, 1028-1051

24. Panayiotis Panayides*a, Miranda Jane Walker. Evaluation of the Psychometric Properties of the Internet Addiction Test (IAT) in a Sample of Cypriot High School Students: The Rasch Measurement Perspective. Europe's Journal of Psychology ,2012, Vol. 8(3), 327-351)

25. Hattingh S, Dreyer $M$ and Ross $S$. Community Nursing. 4th ed. Southran Africa : Southran Co,2012: 305-308.

26. Allender J, Rector C and Warner K. Community Health Nursing. Promoting and Protecting the Public Health. 7th ed. Philadelphia: Wolters Kluwer /Lippincott Williams ,Wilkins Co, 2010:608.

27. Yang-Sook Yoo, Ok-Hee Cho, and Kyeong-Sook Cha. Associations between overuse of the internet and mental health in adolescents. Nursing and Health Sciences (2014), 16, 193200.

28. Lin, S, Tsai, K, Chen, M, Koo, M. (2013). Association between fatigue and internet addiction in female hospital Nurses. Journal of Advancad Nursing, 69:2, 374-83.

29. Currie C, Molcho M, Boyce W, Holstein B, Torsheim T, Richter M. Researching health inequalities in adolescents: the development of the Health Behavior in School-aged Children (HBSC) family affluence scale. Soc. Sci. Med. 2008; 66: 14291436.

30. Goldberg P, , Hillier F. A scaled version of the General Health Questionnaire. Psychological

Medicine, $\quad 1979 ; \quad 9(1)$ : 139145.Available at: https://doi.org/ $10.1017 / \mathrm{S} 0033291700021644$

31. Lyubomirsky, S, , Lepper, $\mathrm{H}$. (1999). A measure of subjective happiness: Preliminary reliability and construct validation. Social Indicators Research, 46, 137-155. Available at: http://sonjalyubomirsky.com/subjectiv e-happiness-scale-shs/

32. Young K. Internet Addiction Test (IAT). An online version is available at http://www.internetoveruse.com/?p=171

33. Bakken, J, Wenzel, G, Gotestam, G, Johansson A. and Qren, A. Internet addiction among Norwegian adults: A stratified probability sample study. Scandinavian Journal of Psychology, 
2009; 50(2): 121- 27.https://doi.org /10.1111/j.1467-450.2008.00685.

34. Arvind S, Sahu R, Kasari P, Sharma R, Internet addiction among professional courses students: A study from central India, International Journal of Medical Science and Public Health, [Online] 2014, Vol 3; Issue 9, accessed on 2/7/17, Available from: http://www. ejmanager.com/mnstemps/67/671400998592.pdf

35. Shaheen H,Farahat T. and Gaber H. Problematic Internet Use among Medical School Students in Menoufia University Egypt. J Child Adolesc Behav 2016, 3:4.

36. Parel $\mathbf{J}$ and Thomas L. Level of Internet Addiction Among Nursing Students: A Cross Sectional Survey. Asian J. Nursing Edu. and Research, October- December 2017; 7(4): 466470.

37. Gopala VV, Srijampana R, Endreddy RA, Prabhath K, Bhagawan R. Prevalence and patterns of internet addiction among medicalstudents. Med J DY PatilUniv2014;7:709 - 13.

38. Aylaz R, Güneş G, Günaydın Y, Kocaer M. and Pehlivan E. Problematic internet usage among high school students and the relevant factors. Turk J Public Health
2015;13(3) Available online at: http://tjph.org/ojs/index.php/

39. Khalil A, Alharbi N, Alhawasawi H. and Albander A. Prevalence of Internet Addiction among Nursing Students and the Association with their Academic Performance and Mental Health. Athens Journal of Health, 2016; 3 (43): 291-306.

40. Mohamed H, Shehzad K, Ahmad S. and Wadi $M$. Internet Use and Addiction Among Medical Students in Qassim University, Saudi Arabia. Sultan Qaboos University Med J, 2019; 19(2):142-147. , basic research

41. Cao H, Sun Y, Wan Y, Hao J, Fangbiao F. Problematic Internet use in Chinese adolescents and its relation to psychosomatic symptoms and life satisfaction. BMC Public Health 2011; 11:802-810.

42. Mazhari S. (2012) The prevalence of problematic internet use and the related factors in medical students, Kerman, Iran. Addiction and Health 4(3-4): 8794.

43. Kheirkhah F, GhabeliJuibary A, Gouran A (2010) Internet Addiction, Prevalence and Epidemiological Features in Mazandaran Province, Northern Iran. The Iranian Red Crescent Medical Journal 12(2): 133137. 
44. Malak M, Khalifeh A. and Shuhaiber A. Prevalence of Internet Addiction and associated risk factors in Jordanian school students. Computers in Human Behavior, (2017); 70 :556-563

45. Andersona E, Steenb E. and Stavropoulosa V. Internet use and Problematic Internet Use: a systematic review of longitudinal research trends in adolescence and emergent adulthood . International Journal of Adolescence and Youth, 2016; 1-27.

46. Alavi S S, Maracy M R, and Eslami M. The effect of psychiatric symptoms on the internet addiction disorder in Isfahan's University students. Journal of Research in Medical Sciences, 2011 Jun; 16(6): 793-800.)

47. Mittal, V. A, Dean, D. J, , Pelletier, A. (2013). Internet addiction, reality substitution and longitudinal changes in psychoticlike experiences in young adults. Early Intervention Psychiatry, 7, 261-269. doi:10.1111/j.1751-7893. 2012.00390.x

48. Dong, G, Lu, Q, Zhou, H, Zhao, X. (2011). Precursor or sequela: Pathological disorders in people with Internet addiction disorder. PLoS One, 6, e14703. doi:10.1371/journal. pone.0014703

49. Çam, H, , Nur, N. (2015). A Study on the prevalence of Internet addiction and its association with psychopathological symptoms and obesity in adolescents. TAF Preventive Medicine Bulletin, 14(3), 81-188. Available at:http://dx. doi.org/10.5455/pmb.20141016033204 50. Goel, D, Subramanyam, A, Kamath, R. (2013). A study on the prevalence of Internet addiction and its association with psychopathology in Indian adolescents. Indian Journal of Psychiatry, 55(2), 140. http://dx.doi. org/10.4103/0019- 5545.111451.

51. Tang, J, Yu, Y, Du, Y, Ma, Y, Zhang, D, , Wang, J. (2014). Prevalence of internet addiction and its association with stressful life events and psychological symptoms among adolescent Internet users. Addictive Behavior, 39(3), 744-747.

52. Kaynak S. , Duran S, Karada A. Determination of the Relationship Between Internet Addiction and the Level of Loneliness Among Nurses. Journal of health and nursing management, 2018; 5 (1): 27:35.

53. Şahin, C. (2011). An analysis of Internet addiction levels of individuals according to various variables. TOJET: The Turkish Online Journal of Educational Technology, 10:4, 60-66.

54. Tonioni, F, D’Alessandris, L, Lai, C, Martinelli, D, Corvino, S, Vasale, M, 
et al. (2012). Internet addiction: Hours spent online, behaviors and psychological symptoms. General Hospital Psychiatry, 34:1, 80-87. https://doi.org/10.1016/j.genhosppsych .2011 .09 .013

55. Wu, C, Lee, M, Liao, S, Chang, L. (2015). Risk factors of Internet addiction among internet users: An online questionnaire survey, 13:10, 110.

56. Rücker, J, Akre, C, Berchtold, A, , Suris, J. C. (2015). Problematic Internet use is associated with substance use in young adolescents. Acta Paediatrica (Oslo, Norway: 1992), 104(5), 504e507. http://dx.doi.org/10.1111/apa.12971.

57. Ko, C, Yen, J, Yen, C, Chen, C, , Chen, C. (2012). The association between internet addiction and psychiatric disorder: A review of the literature. European Psychiatry: The Journal of the Association of European Psychiatrists, 27(1), 1e8. http:// dx.doi.org/10.1016/j.eurpsy.2010.04.011.

58. Sasmaz, T, Oner, S, Kurt, A, Yapıcı, $\mathrm{G}$, Yazıc1, A, Bu_gdayc1, R, et al. (2013). Prevalence and risk factors of Internet addiction in high school students. European Journal of Public Health, 24(1), 15e20. http://dx.doi.org/ 10.1093/eurpub/ckt051
59. Lam LT, Peng ZW, Mai JC, Jing J. Factors associated with Internet addiction among adolescents. Cyberpsychol. Behav. 2009; 12: 551- 555. 60. Tsai HF, Cheng SH, Yeh TL et al. The risk factors of Internet addiction a survey of university freshmen. Psychiatry Res. 2009; 167: 294-299.

61. Alhantoushi, M, Alabdullateef, S. (2014). Internet addiction among secondary school students in Riyadh city, its prevalence, correlates and relation to depression: A questionnaire survey. International Journal of Medical Science and Public Health, 3(1), 1. http://dx.doi.org/10.5455/ ijmsph.2013.130920131.

62. Akın A. The Relationships between internet addiction, subjective vitality, and subjective happiness. Cyberpsychology, behavior, and social networking, 2012; 15 (8): 404-410. 